\title{
MASYARAKAT EKONOMI ASEAN: HARAPAN DAN TANTANGAN BAGAIMANA DAYA SAING INDONESIA DI ASEAN
}

\author{
Wardoyo \\ Universitas Muhammadiyah Tangerang \\ wwardoyo@hotmail.com
}

Keyword
Asean Economic Community,
Competitiveness, Single Market.

Abstract

Asean Economic Community (AEC) was officially started on 31 December 2015. The objectives of AEC were to integrate diversity of Asean economy into a single market with 625 million people of inhabitant. AEC is expected to be a new market force in Asean and improve economic development of Asean member countries. AEC will allow a free movement of goods and services, skilled labors and flow of capital in Asean countries. However, implementation of the AEC framework is not an easy task; Trade policies, mobility of workers, diversity on politic, social, and economy including rapid growth of economic development in China are some challenges to fully integrate Asean countries in a single market of AEC. For Indonesia, AEC provides opportunities to enhance export of goods and services in Asean countries. Therefore competitiveness of Indonesian products in the AEC market should be improved. Based upon components of competitivess reported by World Economic Forum (2014), Indonesia was in the top 5 among Asean member countries, except competitiveness on efficiency in labor market that was in the lowest position.

C2017 JMB, All right reserved

\section{PENDAHULUAN}

Prinsip dasar yang melandasi pembentukan Masyarakat Ekonomi Asean (MEA) disusun dan disetujui oleh pemimpin negara-negara yang tergabung dalam ASEAN pada Pertemuan Asean ke-13, tanggal 20 November 2007 di Singapura. Secara resmi MEA mulai berlaku pada tanggal 31 Desember 2015 yang menandai terbentuknya kekuatan blok baru di Asia. MEA terdiri dari 10 negara anggota Asean: Brunei, Kamboja, Indonesia, Laos, Malaysia, Myanmar, Filipina, Singapore, Thailand dan Vietnam. Masing-masing negara mempunyai faktor daya tarik tersendiri bagi investor diantaranya profile penduduk yang menguntungkan, sumber daya alam yang melimpah dan tenaga kerja yang murah.

Paper ini menguraikan tujuan, dan harapan dalam pembentukan MEA serta tantangan yang dihadapi untuk mewujudkannya.
Selanjutnya, untuk mengetahui kesiapan Indonesia dalam menghadapi pasar tunggal MEA, paper ini menjelaskan pula daya saing Indonesia diantara negara-negara Asean dengan menggunakan global.

\section{TUJUAN PEMBENTUKAN MEA}

Pembentukan MEA bertujuan untuk menyatukan ekonomi Asia Tenggara yang beragam menjadi pasar tunggal dengan jumlah penduduk 625 juta jiwa yang secara keseluruhan memiliki Produk Domestik Brutto (PDB) senilai US\$2.5 triliun pada tahun 2014 (Sellier, 2016). Bidang kerjasama diantara negara-negara anggota Asean dalam MEA meliputi:

I. Pengembangan SDM dan peningkatan kapasitas,

2. Pengakuan kualifikasi profesi,

3. Konsultasi lebih dekat dalam kebijakan makroekonomi dan keuangan,

4. Kebijakan pendanaan dalam perdagangan, 
5. Perbaikan infrastruktur dan komunikasi,

6. Pengembangan transaksi elektronik melalui e-Asean,

7. Memadukan industri antar wilayah untuk meningkatkan sumberdaya regional,

8. Meningkatkan keterlibatan sektor swasta dalam pembangunan MEA.

Secara singkat, MEA akan merubah kegiatan ekonomi Asean menjadi ekonomi dengan pergerakan yang lebih bebas untuk barang, jasa, tenaga kerja trampil dan arus modal di wilayah Asean. Dengan menjadi basis produksi dan pasar tunggal Asean, MEA akan meningkatkan daya saing dan konektivitas antar wilayah yang akan membuat agregat produksi meningkat 7\% pada tahun 2025 .

Banyak harapan dengan terbentuknya MEA, yaitu MEA diharapkan dapat menghubungkan antara negara-negara yang ekonominya belum berkembang (Kamboja, Laos, Myanmar, Vietnam), dengan negara-negara yang ekonominya sudah maju (Brunei, Singapura, Malaysia, Filipina, Indonesia), dan dapat membawa perkembangan ekonomi yang merata di kawasan ini. Asean diharapkan akan menjadi kekuatan ekonomi terbesar ke-4 di dunia pada tahun 2030, sesudah Amerika Serikat, dan Cina. MEA juga diharapkan dapat memberikan prospek positif bagi dunia usaha/bisnis, karena hambatan dagang akan lebih rendah (tarif, nontarif dihapus), arus barang jasa yang diperdagangkan akan meningkat, akses pasar lebih luas, dan adanya insentif lain yang menarik.

\section{TANTANGAN YANG DIHADAPI}

Namun demikian jalan kearah terbentuknya MEA yang terpadu secara menyeluruh (fully integrated) akan menghadapi tantangan yang tidak mudah, sehingga perbentukan MEA dapat membawa Asean ke persimpangan jalan yang kritis (Low, 2016). Tantangan tersebut adalah:

I. Hambatan perdagangan

Meskipun hambatan tarif ekspor produk dari negara Asean dihapuskan, tetapi investasi usaha sepanjang perbatasan menghadapi isue non-tarif seperti perlunya lisensi dan persyaratan tertentu dalam penggunaan lahan. Arus jasa juga mendapat hambatan. Kebijakan perdagangan jasa di Asean lebih ketat dan kompleks daripada wilayah lain di dunia.

\section{Mobilitas tenaga kerja}

Mobilitas tenaga kerja menjadi tantangan lain. Antara tahun 2005 - 2012, negara-2 Asean menanda tangani penyiapan pengakuan timbal-balik (mutual recognition arrangements/MRA) dalam 6 sektor yaitu: tehnik (engineering), keperawatan, arsitektur (architecture), obat-2an (medicine), kedokteran gigi (dentistry), dan pariwisata (tourism). Perjanjian ini memungkinkan setiap negara mengakui pendidikan dan pengalaman, lisensi dan sertifikat yang telah diperoleh di negara lain di Asean. Tetapi implementasi pada bidang ini masih lamban karena pada prakteknya, regulasi dan legislasi nasional yang ada di masing-masing negara bertentangan dengan komitmen wilayah tentang mobilitas tenaga kerja dan tidak mendukung mobilitas yang terjadi di perbatasan bagi tenaga profesional.

3. Keberagaman politik, ekonomi dan sosial budaya

Tantangan selanjutnya adalah adanya keberagaman politik, ekonomi dan sosial budaya. Keadaan politik di negara-negara Asean dapat dikatakan kurang stabil, demokrasi di Indonesia dan Filipina sering terjadi kegaduhan (tidak stabil), hal yang sama terjadi dengan diktator komunis di Vietnam, dan Junta militer di Thailand;

Dari segi ekonomi, terjadi kesenjangan yg lebar dalam pembangunan ekonomi diantara negara-negara Asean. Disatu pihak terdapat negara-negara yang termasuk sebagai negaranegara modern yg tumbuh cepat (Asean-6: Singapura, Brunei, Malaysia, Indonesia, Thailand, Filipina). Di lain pihak, terdapat negara-negara yang pembangunan ekonominya masih tertinggal dan miskin (Kamboja, Laos, Myanmar, Vietnam/KLMV). Sebagai contoh, pada tahun 2013, total perdagangan Myanmar senilai US\$23 milyar, dibandingkan dengan Singapura sebesar US\$ 783 milyar.

Pertumbuhan ekonomi yang tidak seimbang dan tidak berkelanjutan bisa mengarah pada: (i) extenalitas negatif dan kemiskinan yg makin memburuk, dan (ii) ketidakseimbangan dalam kesejahteraan, sumber daya, tenaga, dan kesempatan berusaha (antar negara, antara kaya dan miskin, dan antara pria dan wanita). Oleh karena itu, MEA harus menghubungkan antara Asean-6 dan CLMV melalui tujuan yg telah ditetapkan untuk mengurangi kesenjangan pembangunan ekonomi, memperkuat infrastruktur antar wilayah, dan mengurangi beban administrasi 
regulasi nasional dalam menciptakan investasi asing dan bisnis baru. Namun, tujuan ini perlu waktu lama (puluhan tahun) untuk mencapainya jika Asean tidak menyiapkan perangkat institusi yg memadai dan sumber daya yg memberikan dorongan akhir pada integrasi ekonomi.

Secara budaya, Asean mempunyai kemajemukan dalam agama, bahasa, etnis, dan cara hidup. Sebagai contoh: Malaysia dan Indonesia adalah negara dengan penduduk muslim sedangkan Myanmar dan Filipina masing-masing berpenduduk umumnya budha, dan Katholik. Meskipun keragaraman budaya mempunyai daya tarik tersendiri (wisata), tetapi dapat juga menjadi penyebab hubungan yang tidak harmonis diantara negara-negara Asean.

4. Institusi Asean kurang kokoh

Asean memerlukan institusi yang dapat membentuk mekanisme regional untuk memastikan koordinasi yang lancar antara pelaku pemerintahan dari berbagai sektor nasional, kementerian dan badan yang berbeda. Misalnya, meskipun $95 \%$ tarif angkutan dihapuskan, tetapi hambatan tarif barang dan jasa tidak dihapuskan, yang membuat perdagangan khususnya di wilayah perbatasan menjadi menyakitkan. Undangundang konsumen, hak cipta, tataguna lahan, dan aturan investasi belum diharmonisasikan pada tingkat regional; hal yang sama terjadi pada struktur perbankan terpadu, bersamaan dengan tidak adanya persetujuan tentang mata uang yang dapat diterima bersama, nampaknya akan menghambat akses pasar untuk usaha kecil dan menengah.

Sekretariat Asean sebagai Institusi yang mengurus organisasi dan kegiatan Asean kurang kuat dilihat dari segi tenaga kerja, anggaran dan koordinasi; Sekretariat Asean yang ada memiliki staf tidak lebih dari 400 orang dengan anggaran tahunan kurang dari US\$ 17 juta, sehingga menimbulkan ketidakpastian apakah Asean dapat mencapai target yang ada dalam MEA yang menyebabkan ketidakpastian dalam implementasi komitmen MEA dan pencapaian target nasional pemerintah masing-masing negara anggota Asean.

5. Kemajuan ekonomi dan militer Cina dan India menjadi pesaing.

Saat ini, kekuatan ekonomi dan militer Cina dan India tumbuh pesat, maka Asean dengan MEA-nya perlu mencari posisi sebagai alternatif berkompetisi. Kegiatan ekonomi mempunyai pengaruh yang sama dengan pengaruh politik, dan integrasi ekonomi akan menjadi tidak signifikan jika tidak didukung reformasi politik yang baik. Namun dalam realitasnya, masalah terkait politik dan keamanan tidak berkurang. Situasi keamanan di wilayah Asia Pasifik, ikut menentukan arah jalannya Asean dimasa datang. Sementara itu, program modernisasi militer Cina yang masif yang melengkapi angkatan lautnya dengan kemampuan operasi jauh melampaui wilayah lautnya, telah menyulut perdebatan di wilayah ini. Trend serupa, pertandingan kekuatan antara Cina dan Jepang mendorong persaingan di laut Cina Timur, sementara keterlibatan yg progresif Amerika Serikat (AS) dalam perselisihan melalui aliansi historis dengan Vietnam, Filipina dan Jepang telah menjadikan perasaan tidak percaya, dan polarisasi yg meluas dari negara anggota Asean. Keterlibatan kembali AS ditunjukan oleh patroli militer bersama Filipina dan hadirnya kapal militer AS di laut Cina Selatan (detik.com, 14 April 2016), yang dianggap sebagai kegiatan provokasi oleh Cina. Apabila hal ini terus terjadi maka Asean dapat dianggap gagal menepati janjinya yaitu meningkatkan perdamaian dan kerjasama Asean.

\section{DAYA SAING INDONESIA PADA TINGKAT ASEAN DAN GLOBAL}

Terbentuknya Masyarakat Ekonomi Asean merupakan peluang emas, dan bukan sebagai ancaman yang perlu ditakuti. Pemerintah, pengusaha, dan segenap pemangku kepentingan harus bersatu dalam menghadapi MEA, agar negara kita bisa tampil sebagai pemenang. Daya saing menjadi faktor penting dalam MEA. Daya saing dapat diartikan sebagai kemampuan untuk memperoleh posisi dan mempertahankan posisi tersebut dalam pasar dimana terjadi persaiangan antar pengusaha, antar pesaing dan secara makro ekonomi diantara pelaku ekonomi nasional. Kekuatan daya saing ditentukan oleh fondasi yang mempunyai dasar-dasar yang kokoh meliputi alam/fisik, perusahaan, inovasi/invensi, pemerintah dan masyarakat (Tambunan, 2015). Tingkat Produktivitas menentukan tingkat kesejahteraan yang dapat dicapai oleh suatu perekonomian. Tingkat produktivitas juga menentukan tingkat pendapatan yang diperoleh dari investasi suatu perekonomian yang merupakan pendorong utama tingkat 
pertumbuhan. Jadi, perekonoman yang lebih berdaya saing adalah perekonomian yang tumbuh lebih cepat sepanjang waktu.

Banyak komponen yg mendorong produktivitas dan daya saing. Dalam Global Competitiveness Index (GCl), komponenkomponen tersebut dibagi dalam 12 pilar, dan dikelompokan dalam tiga sub indeks yaitu basic requirements (persyaratan dasar), efficiency enhancers (peningkatan efisiensi), dan innovation and sophistication (inovasi dan kecanggihan). Secara rinci kerangka kerja 12 pilar tersebut dapat dilihat pada Gambar I.

Sejak tahun 2005 World Economic Forum (WEF) telah melakukan analisis daya saing dengan menggunakan Global Competitiveness Index $(\mathrm{GCl})$ yang mengukur daya saing nasional suatu negara berdasarkan prinsipprinsip mikro dan makro ekonomi (Schwab,
20/4). Disamping itu, daya saing dikaitkan pula dengan dimensi sosial dan lingkungan dalam suatu hubungan yang kompleks. WEF (2014) mendifinisikan daya saing sebagai seperangkat institusi, kebijakan, dan faktor-faktor yg menentukan tingkat produktivitas suatu negara.

Untuk laporan daya saing global 201420I5, WEF mengumpulkan data dari I 44 negara di dunia guna menghitung $\mathrm{GCl}$ berdasarkan 12 pilar tersebut. Nilai atau score $\mathrm{GCl}$ berkisar antara I (terendah) sampai dengan 7 (tertinggi). WEF mengumpulkan data dari lembaga internasional seperti UNESCO, IMF dan WHO. Karena keterbatasan data yang tersedia maka beberapa negara diantaranya Brunei Darussalam tidak masuk dalam laporan $\mathrm{GCl}$ ini.

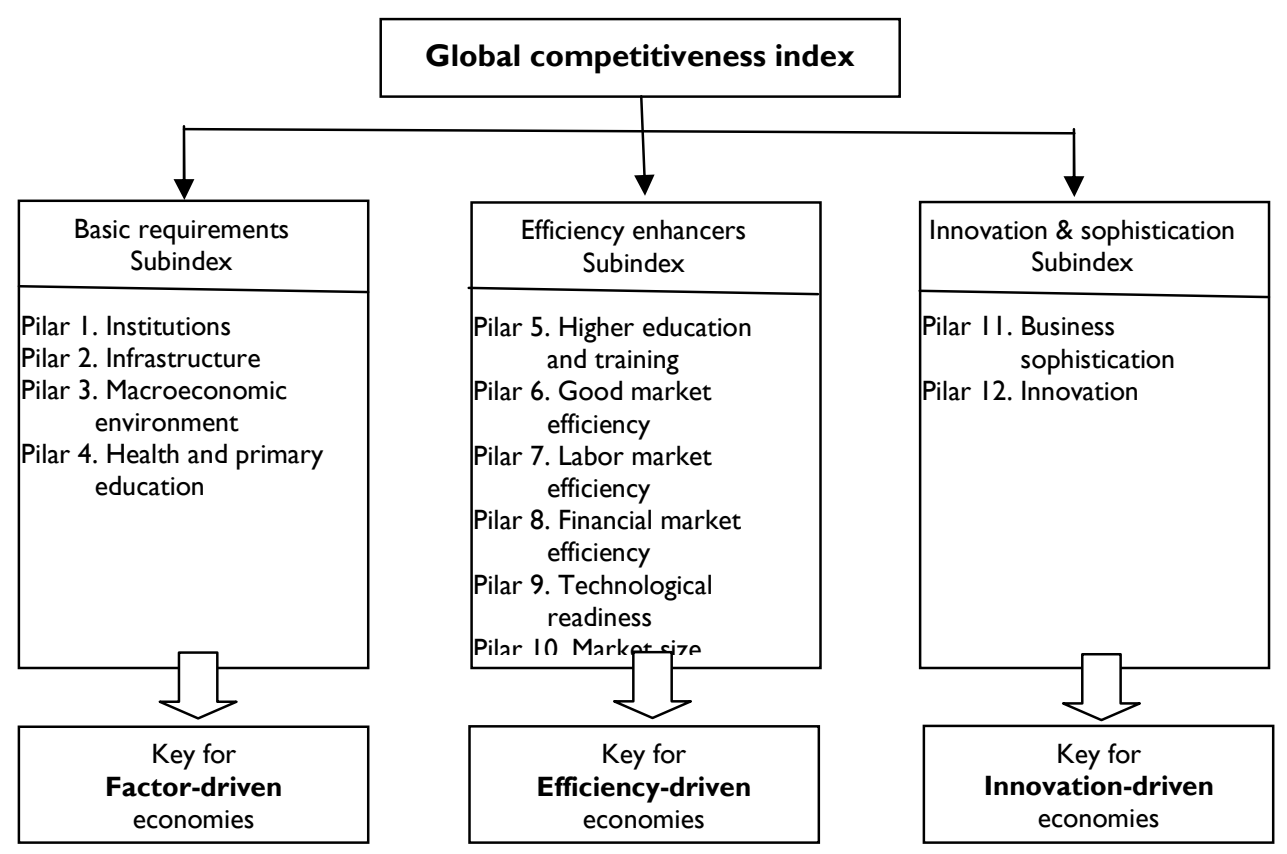

Gambar I. Susunan Indeks daya saing global (WEF, 20I4).

\section{A. Sub Indeks persyaratan dasar (basic requirements)}

Sub indeks ini berkaitan dengan tingkat pembangunan suatu negara. Negara yang masih pada tahap awal pembangunan maka kegiatan ekonomi tergantung kekayaan alam, tenaga kerja dan infrastruktur yang ada (factor driven economy). Sub indeks ini terdiri dari pilar: kelembagaan, infrastruktur, keadaan ekonomi makro, dan kesehatan \& pendidikan dasar.

I. Kelembagaan (institutions)

Aturan kerja secara administratif dan hukum mendasari berjalannya fungsi suatu lembaga/institusi dimana individu, perusahaan, dan pemerintah berinteraksi untuk meningkatkan kesejahteraan masyarakat di negara tsb. Kualitas institusi memberikan arah kuat terhadap daya saing dan pertumbuhan ekonomi karena menentukan dalam keputusan berinvestasi dan berproduksi, yang mempunyai peranan kunci dalam distribusi manfaat dari hasil kegiatan ekonomi, dan perumusan strategi dan kebijakan pembangunan. Dari segi kelembagaan ini, daya saing Singapura masuk 10 besar dunia (score 5,98), dan nomor satu di Asean (Tabel I), sedangkan Indonesia berada di urutan ke-3 di 
Asean (score 4,II) setelah Singapura (score 5,98) dan Malaysia (score 5, II).

Tabel I. Daya saing institusi di Asean

\begin{tabular}{|r|l|r|r|}
\hline No. & \multicolumn{1}{|c|}{ Negara } & \multicolumn{1}{c|}{ Rank Dunia } & \multicolumn{1}{c|}{ Score } \\
\hline I & Singapura & 3 & 5,98 \\
\hline 2 & Malaysia & 20 & $5,1 \mathrm{I}$ \\
\hline 3 & Indonesia & 53 & $4,1 \mathrm{I}$ \\
\hline 4 & Laos & 63 & 3,92 \\
\hline 5 & Filipina & 67 & 3,86 \\
\hline 6 & Thailand & 84 & 3,66 \\
\hline 7 & Vietnam & 92 & $3,5 \mathrm{I}$ \\
\hline 8 & Kamboja & $\mathrm{II}$ & 3,25 \\
\hline 9 & Myanmar & 136 & 2,8 \\
\hline
\end{tabular}

Sumber: Laporan WEF (2014).

2. infrastruktur (infrastructure)

Infrastruktur yang tersebar di seluruh negeri sangat penting untuk memastikan perekonomian berfungsi efektif dan efisien, karena infrastruktur menentukan lokasi kegiatan ekonomi dan jenis-jenis kegiatan atau sektor yang perlu dibangun di negara tsb. Dalam hal infrastruktur, Singapura termasuk dalam 10 besar dunia (ranking 2 score 6,54), dan berada diurutan teratas di Asean (Tabel 2), dan Indonesia di posisi ke-4 (score 4,37) setelah Singapura, Malaysia (score 5,46), dan Thailand (score 4,58). Di Indonesia infrastruktur seperti jalan, tenaga listrik masih terbatas khususnya di luar pulau Jawa.

Tabel 2. Daya saing infrastruktur di Asean

\begin{tabular}{|c|l|r|r|}
\hline No & Negara & \multicolumn{1}{|l|}{ Rank Dunia } & \multicolumn{1}{l|}{ Score } \\
\hline I & Singapura & 2 & 6,54 \\
\hline 2 & Malaysia & 25 & 5,46 \\
\hline 3 & Thailand & 48 & 4,58 \\
\hline 4 & Indonesia & 56 & 4,37 \\
\hline 5 & Vietnam & 81 & 3,74 \\
\hline 6 & Filipina & 91 & 3,49 \\
\hline 7 & Laos & 94 & 3,38 \\
\hline 8 & Kamboja & 107 & 3,05 \\
\hline 9 & Myanmar & 137 & 2,05 \\
\hline
\end{tabular}

Sumber: Laporan WEF (20I4).

\section{Lingkungan ekonomi makro (Macroeconomic environment)}

Stabilitas makro ekonomi sangat penting bagi dunia usaha untuk berkontribusi signifikan dalam daya saing suatu negara. Kondisi ekonomi makro seperti tingkat suku bunga, inflasi, pajak, defisit anggaran, nilai tukar mata uang dsb. merupakan fundamental ekonomi penting untuk stabilitas ekonomi makro. Dalam daya saing kondisi ekonomi makro, negara-negara Asean tidak ada yang masuk dalam 10 besar dunia. Diantara negara-negara anggota Asean,
Singapura memiliki daya saing yang terbaik (Tabel 3), dan Indonesia berada di urutan ke-4, lebih baik daripada Malaysia yang berada diurutan ke-5.

Tabel 3. Daya saing ekonomi makro di Asean

\begin{tabular}{|r|l|r|r|}
\hline No. & Negara & Rank Dunia & Score \\
\hline I & Singapura & 15 & 6,13 \\
\hline 2 & Thailand & 19 & 6,01 \\
\hline 3 & Filipina & 26 & 5,76 \\
\hline 4 & Indonesia & 34 & 5,48 \\
\hline 5 & Malaysia & 44 & 5,26 \\
\hline 6 & Vietnam & 75 & 4,66 \\
\hline 7 & Kamboja & 80 & 4,6 \\
\hline 8 & Myanmar & 116 & 4 \\
\hline 9 & Laos & 124 & 3,78 \\
\hline Sumber: Laporan WEF (20I4).
\end{tabular}

4. Kesehatan dan pendidikan dasar (Health and primary education)

Angkatan kerja yang sehat merupakan faktor kunci dalam daya saing dan produktivitas suatu negara. Pendidikan dasar meningkatkan efisiensi setiap individu tenaga kerja, maka kurangnya pendidikan dasar akan menjadi kendala dalam pengembangan usaha, akan sulit untuk meningkatkan nilai tambah produk. Dalam hal ini, Singapura memiliki daya saing yang terbaik, dan Indonesia di urutan ke-5 setelah Malaysia, Vietnam dan Thailand (Tabel 4). Vietnam yang pada tiga pilar sebelumnya berada di urutan papan bawah, memiliki daya saing yang baik untuk kesehatan dan pendidikan dasar mengungguli Thailand dan Indonesia.

Tabel 4. Daya saing kesehatan dan pendidikan dasar di Asean

\begin{tabular}{|r|l|r|r|}
\hline \multicolumn{1}{|l|}{ No } & Negara & \multicolumn{1}{|l|}{$\begin{array}{l}\text { Rank } \\
\text { Dunia }\end{array}$} & \multicolumn{1}{c|}{ Score } \\
\hline I & Singapura & 3 & 6,73 \\
\hline 2 & Malaysia & 33 & 6,28 \\
\hline 3 & Vietnam & $6 \mathrm{I}$ & 5,86 \\
\hline 4 & Thailand & 66 & 5,8 \\
\hline 5 & Indonesia & 74 & 5,67 \\
\hline 6 & Laos & 90 & 5,44 \\
\hline 7 & Kamboja & $9 \mathrm{I}$ & 5,44 \\
\hline 8 & Filipina & 92 & $5,4 \mathrm{I}$ \\
\hline 9 & Myanmar & $\mathrm{II}$ & 4,59 \\
\hline
\end{tabular}

Sumber: Laporan WEF (20|4).

\section{B. Sub-indeks peningkatan efisiensi (efficiency enhancers)}

Untuk negara dengan produktivitas yang tinggi maka efisiensi merupakan faktor kunci (efficiency driven economy). Pilar yang masuk sub Indeks ini meliputi pendidikan tinggi dan 
pelatihan, efisiensi pasar barang, efisiensi pasar tenaga kerja, pengembangan pasar uang, kesiapan teknologi, dan ukuran pasar.

I. Pendidikan tinggi dan pelatihan (Higher education and training)

Ekonomi global menuntut suatu negara untuk memiliki pusat-pusat tenaga kerja terdidik dengan baik, tenaga kerja yang dapat melaksanakan pekerjaan yg rumit, dan dapat menyesuaikan dengan cepat terhadap perubahan lingkungan dan perubahan kebutuhan dari sistem produksi. Singapura memiliki daya saing terbaik di Asean (No. 2 di dunia) untuk tenaga kerja yang berpendidikan tinggi dan pelatihan, sedangkan Indonesia di urutan ke-4 setelah Singapura, Malaysia, dan Thailand (Tabel 5).

Tabel 5. Pendidikan tinggi dan pelatihan di Asean

\begin{tabular}{|r|l|r|r|}
\hline No & Negara & Rank Dunia & \multicolumn{1}{l|}{ Score } \\
\hline 1 & Singapura & 2 & 6,09 \\
\hline 2 & Malaysia & 46 & 4,8 \\
\hline 3 & Thailand & 59 & 4,58 \\
\hline 4 & Indonesia & 61 & 4,53 \\
\hline 5 & Filipina & 64 & 4,45 \\
\hline 6 & Vietnam & 96 & 3,74 \\
\hline 7 & Laos & 110 & 3,28 \\
\hline 8 & Kamboja & 123 & 2,92 \\
\hline 9 & Myanmar & 135 & 2,44 \\
\hline
\end{tabular}

Sumber: Laporan WEF (20I4).

2. Efisiensi pasar barang (Goods market efficiency)

Negara dengan pasar barang yang efisien mempunyai posisi baik untuk memproduksi bauran barang dan jasa sesuai kondisi supply dan demand-nya dan untuk memperdagangkan barang jasa tsb secara efisien dalam perekonomian. Persaingan pasar yang sehat baik domestik maupun internasional sangat penting untuk mendorong efisiensi pasar dan produktivitas usaha, dan hanya perusahaan yang efisien yang memproduksi barang yang diminta pasar. Pemerintah diharapkan melakukan Intervensi seminimal mungkin untuk memperlancar kegiatan bisnis. Efisiensi pasar barang di Singapura mempunyai tingkat daya saing nomor satu di dunia (di Asean juga) dengan score 5,64. Malaysia nomor 7 di dunia dan nomor 2 di Asean, dan Indonesia nomor 48 di dunia dan nomor 4 di Asean.

Tabel 6. Daya saing efisiensi pasar barang di Asean

\begin{tabular}{|r|l|r|r|}
\hline No & Negara & Rank Dunia & Score \\
\hline I & Singapura & I & 5,64 \\
\hline 2 & Malaysia & 7 & 5,42 \\
\hline
\end{tabular}

\begin{tabular}{|r|l|r|r|}
3 & Thailand & 30 & 4,74 \\
\hline 4 & Indonesia & 48 & 4,54 \\
\hline 5 & Laos & 59 & 4,41 \\
\hline 6 & Filipina & 70 & 4,32 \\
\hline 7 & Vietnam & 78 & 4,24 \\
\hline 8 & Kamboja & 90 & 4,17 \\
\hline 9 & Myanmar & 130 & 3,68 \\
\hline
\end{tabular}

Sumber: Laporan WEF (20I4).

3. Efisiensi pasar tenaga kerja (Labor market efficiency)

Efisiensi dan fleksibilitas pasar tenaga kerja sangat penting untuk menjamin bahwa tenaga kerja dialokasikan dan digunakan secara efektif dalam kegiatan ekonomi dan diberikan insentif yang memungkinkan bagi mereka untuk bekerja sebaik-baiknya. Oleh karena itu, pasar tenaga kerja harus mempunyai fleksibilitas yang memudahkan perpindahan tenaga kerja dari satu tempat ke tempat lain secara cepat dan murah, dan memungkinkan terjadinya fluktuasi upah tanpa menimbulkan gangguan sosial. Singapura menduduki peringkat 2 dunia dan nomor satu di Asean dalam daya saing efisiensi pasar tenaga kerja, sedangkan Indonesia berada pada peringkat 110 dunia dan di Asean nomor 9 (posisi terbawah).

Tabel 7. Daya saing efisiensi pasar tenaga kerja di Asean

\begin{tabular}{|r|l|r|r|}
\hline \multicolumn{1}{|l|}{ No } & Negara & Rank Dunia & \multicolumn{1}{|l|}{ Score } \\
\hline 1 & Singapura & 2 & 5,69 \\
\hline 2 & Malaysia & 19 & 4,8 \\
\hline 3 & Kamboja & 29 & 4,63 \\
\hline 4 & Laos & 34 & 4,59 \\
\hline 5 & Vietnam & 49 & 4,37 \\
\hline 6 & Thailand & 66 & 4,24 \\
\hline 7 & Myanmar & 72 & 4,21 \\
\hline 8 & Filipina & 91 & 4,03 \\
\hline 9 & Indonesia & 110 & 3,81 \\
\hline
\end{tabular}

Sumber: Laporan WEF (20I4).

4. Pengembangan pasar uang (Financial market development)

Krisis ekonomi dan keuangan telah menunjukan peranan penting dari sektor keuangan yang berfungsi secara baik dalam kegiatan perekonomian. Sektor keuangan yang efisien mengalokasikan sumber daya yang disimpan baik oleh penduduk negara tsb, maupun dari luar negeri, pada penggunaan yang paling efektif. Pasar uang menyalurkan sumber daya tsb kepada para pengusaha atau proyek investasi dengan tingkat pengembalian (rate of return) tertinggi dan tidak merupakan konektivitas politis. Penilaian risiko yang layak dan menyeluruh merupakan faktor kunci pasar keuangan yang baik. Singapura dan Malaysia 
termasuk 10 besar (nomor I dan 2 di Asean) dalam daya saing pengembangan pasar uang, sedangkan Indonesia di urutan ke 4 dengan score 4,45 .

Tabel 8. Daya saing Pengembangan pasar uang di Asean

\begin{tabular}{|r|l|r|r|}
\hline No & Negara & Rank Dunia & \multicolumn{1}{l|}{ Score } \\
\hline 1 & Singapura & 2 & 5,84 \\
\hline 2 & Malaysia & 4 & 5,6 \\
\hline 3 & Thailand & 34 & 4,61 \\
\hline 4 & Indonesia & 42 & 4,45 \\
\hline 5 & Filipina & 49 & 4,37 \\
\hline 6 & Kamboja & 84 & 3,8 \\
\hline 7 & Vietnam & 90 & 3,77 \\
\hline 8 & Laos & 101 & 3,69 \\
\hline 9 & Myanmar & 139 & 2,58 \\
\hline
\end{tabular}

Sumber: Laporan WEF (20I4).

\section{Kesiapan teknologi (Technological readiness)}

Dalam dunia yang mengglobal seperti saat ini, teknologi menjadi semakin esensial agar perusahaan dapat lebih bersaing dan meningkat kesejahteraannya. Kesiapan teknologi mengukur kemampuan merubah (agility) dimana perekonomian mengadop teknologi yang ada untuk meningkatkan produktivitas industri, dengan penekanan khusus pada kapasitasnya untuk meningkatkan teknologi informasi dan komunikasi (ICT) sepenuhnya dalam kegiatan sehari-hari dan proses produksi guna meningkatkan efisiensi dan memungkinkan inovasi dalam daya saing. Hampir semua negara Asean daya saingnya rendah dalam kesiapan teknologi. Hanya Singapura yang memiliki daya saing ini cukup baik (nomor 7 dunia, nomor I Asean), negara-negara Asean lainnya diatas ranking 60 dunia.

Tabel 9. Daya saing kesiapan teknologi di Asean

\begin{tabular}{|r|l|r|r|}
\hline No & Negara & Rank Dunia & \multicolumn{1}{l|}{ Score } \\
\hline I & Singapura & 7 & 6,09 \\
\hline 2 & Malaysia & 60 & 4,18 \\
\hline 3 & Thailand & 65 & 3,94 \\
\hline 4 & Filipina & 69 & 3,78 \\
\hline 5 & Indonesia & 77 & 3,58 \\
\hline 6 & Vietnam & 99 & 3,12 \\
\hline 7 & Kamboja & 102 & 3,02 \\
\hline 8 & Laos & 115 & 2,83 \\
\hline 9 & Myanmar & 144 & 2,07 \\
\hline
\end{tabular}

Sumber: Laporan WEF (20I4).

6. Ukuran pasar (Market size)

Besarnya pasar mempengaruhi produktivitas karena pasar yang besar memungkinkan perusahaan memperoleh skala ekonomi. Secara tradisional, pasar yang tersedia bagi perusahaan terkendala oleh batas nasional.
Pada zaman globalisasi, pasar internasional telah menjadi substitusi bagi pasar domestik, terutama untuk negara kecil. Dalam hal ukuran pasar, Indonesia mempunyai daya saing tertinggi (nomor I di Asean, nomor 15 dunia).

Tabel 10. Daya saing ukuran pasar di Asean

\begin{tabular}{|r|l|r|r|}
\hline No & Negara & \multicolumn{1}{|l|}{ Rank Dunia } & \multicolumn{1}{l|}{ Score } \\
\hline I & Indonesia & 15 & 5,34 \\
\hline 2 & Thailand & 22 & 5,09 \\
\hline 3 & Malaysia & 26 & 4,9 \\
\hline 4 & Singapura & 31 & 4,71 \\
\hline 5 & Vietnam & 34 & 4,69 \\
\hline 6 & Filipina & 35 & 4,68 \\
\hline 7 & Myanmar & 70 & 3,7 \\
\hline 8 & Kamboja & 87 & 3,31 \\
\hline 9 & Laos & 121 & 2,67 \\
\hline
\end{tabular}

Sumber: Laporan WEF (20I4).

\section{Sub-indeks Inovasi dan kecanggihan (innovation and sophistication)}

Suatu negara yang tingkat pembangunannya sudah stabil produktivitasnya maka inovasi menjadi penting (innovation driven economy). Dalam hal ini, Kecanggihan dan inovasi dalam usaha merupakan pilar yang membentuk indeks daya saing inovasi dan kecanggihan (innovation and sophistication).

\section{Kecanggihan usaha sophistication)}

Tak diragukan bahwa praktek bisnis yang sophisticated memberikan situasi kondusif untuk efisiensi yang lebih tinggi dalam produksi barang dan jasa. Kecanggihan usaha memperhatikan dua elemen yang saling terhubung: kualitas jaringan bisnis suatu negara dan kualitas operasional dan strategi perusahaan individual. Faktor-2 ini penting bagi negara yang telah mencapai fase pembangunan tingkat lanjut. Dalam hal ini, Indonesia menduduki perinkat ke 3 di Asean setelah Malaysia dan Singapura (Tabel II).

Tabel I I. Daya saing kecanggihan di Asean

\begin{tabular}{|r|l|r|r|}
\hline No & Negara & Rank Dunia & \multicolumn{1}{|l|}{ Score } \\
\hline I & Malaysia & I5 & 5,24 \\
\hline 2 & Singapura & 19 & 5,07 \\
\hline 3 & Indonesia & 34 & 4,47 \\
\hline 4 & Thailand & 41 & 4,4 \\
\hline 5 & Filipina & 46 & 4,33 \\
\hline 6 & Laos & 106 & 3,87 \\
\hline 7 & Vietnam & III & 3,58 \\
\hline 8 & Kamboja & 140 & 2,52 \\
\hline 9 & Myanmar & & \\
\hline
\end{tabular}

Sumber: Laporan WEF (20I4). 
8. Inovasi (Innovation)

Inovasi akan timbul dari pengetahuan tentang teknologi atau non-teknologi baru. Inovasi non teknologi berkaitan dengan knowhow, skill dan kondisi kerja. Indonesia menduduki peringkat ke-3 setelah Singapura dan Malaysia (Tabel I2) dalam daya saing inovasi ini.

Tabel I2. Daya saing inovasi di Asean

\begin{tabular}{|r|l|r|r|}
\hline No & Negara & \multicolumn{1}{|l|}{ Rank Dunia } & \multicolumn{1}{l|}{ Score } \\
\hline 1 & Singapura & 9 & 5,18 \\
\hline 2 & Malaysia & 21 & 4,67 \\
\hline 3 & Indonesia & 31 & 3,93 \\
\hline 4 & Filipina & 52 & 3,48 \\
\hline 5 & Thailand & 67 & 3,28 \\
\hline 6 & Laos & 84 & 3,14 \\
\hline 7 & Vietnam & 87 & 3,12 \\
\hline 8 & Kamboja & 116 & 2,79 \\
\hline 9 & Myanmar & 138 & 2,34 \\
\hline
\end{tabular}

Sumber: Laporan WEF (20I4).

\section{PEMBAHASAN}

\section{Daya Saing}

I. Dari 12 pilar yang diuraikan di atas, indeks daya saing global (GCl) 20I4-20I5 secara keseluruhan disajikan dalam Tabel 13 yang menunjukan bahwa Singapura memiliki daya saing terbaik di Asean (nomor 2 di dunia) dengan score 5,65, dan daya saing terendah adalah Myanmar dengan score 3,24. Sedangkan Indonesia memiliki daya saing pada urutan ke 4 sesudah Singapura, Malaysia dan Thailand dengan score 4,57 (Tabel I3).
Tabel I3. Indeks daya saing keseluruhan di Asean

\begin{tabular}{|c|l|c|c|}
\hline No & \multicolumn{1}{|c|}{ Negara } & Rank Dunia & Score \\
\hline I & Singapura & 2 & 5,65 \\
\hline 2 & Malaysia & 20 & 5,16 \\
\hline 3 & Thailand & 31 & 4,66 \\
\hline 4 & Indonesia & 34 & 4,57 \\
\hline 5 & Filipina & 52 & 4,40 \\
\hline 6 & Vietnam & 68 & 4,23 \\
\hline 7 & Laos & 93 & 3,91 \\
\hline 8 & Kamboja & 95 & 3,89 \\
\hline 9 & Myanmar & 134 & 3,24 \\
\hline
\end{tabular}

Sumber: Laporan WEF (20I4).

2. Tabel I 4 merupakan ringkasan dari 12 indeks daya saing Indonesia yang diuraikan pada seksi sebelumnya. Tabel 14 menunjukan bahwa daya saing Indonesia berada di posisi tengah (moderate) dengan ukuran pasar (market size) memiliki daya saing tertinggi di Asean (nomor I) sedangkan daya saing efisiensi pasar tenaga kerja (Labor market efficiency) menduduki urutan terbawah di Asean. Sehubungan dengan uraian pada ringkasan I dan 2, maka Indonesia perlu mengambil peran untuk meningkatkan daya saing demi kemakmuran dan kesejahteraan bangsa. Langkah yang dapat dilakukan diantaranya menciptakan pemerintahan yang bersih, memberdayakan pasar, mengelola sumber daya alam secara optimal, menyiapkan sumber daya menusia yang handal, dan membentuk generasi muda yang progresif (Basri, 2002).

Tabel I4. Indeks daya saing tiap pilar/komponen untuk Indonesia

\begin{tabular}{|c|l|c|c|c|}
\hline NO & \multicolumn{1}{|c|}{ PILAR } & $\begin{array}{c}\text { RANK } \\
\text { ASEAN }\end{array}$ & $\begin{array}{c}\text { RANK } \\
\text { DUNIA }\end{array}$ & SCORE \\
\hline I & Institusi & 3 & 53 & 4,1 I \\
\hline 2 & Infrastruktur & 4 & 56 & 4,37 \\
\hline 3 & Ekonomi Makro & 4 & 34 & 5,48 \\
\hline 4 & Kesehatan \& Pendd dasar & 5 & 74 & 5,67 \\
\hline 5 & Pendd Tinggi \& Pelatihan & 4 & $6 I$ & 4,53 \\
\hline 6 & Efisiensi pasar barang & 4 & 48 & 4,54 \\
\hline 7 & Efisiensi pasar tenaga kerja & 9 & 110 & 3,81 \\
\hline 8 & Pengembangan pasar uang & 4 & 42 & 4,45 \\
\hline 9 & Kesiapan teknologi & 5 & 77 & 3,58 \\
\hline 10 & Ukuran pasar & 1 & 15 & 5,34 \\
\hline II & Kecanggihan usaha & 3 & 34 & 4,47 \\
\hline I2 & Inovasi & 3 & 31 & 3,93 \\
\hline
\end{tabular}

Sumber: Laporan WEF (20I4).

\section{PENUTUP}

I. Masyarakat Ekonomi Asean (MEA) telah berlaku sejak 3I Desember 20I5. MEA memberikan peluang, tapi juga tantangan dan harapan bagi negara-negara anggota Asean dalam meningkatkan kegiatan perkenomian dan kesejahteraan di kawasan Asean secara lebih terbuka dalam satu pasar tunggal Asean. Dengan MEA maka pergerakan 
barang, jasa, tenaga kerja trampil dan arus modal di wilayah Asean akan lebih bebas.

2. MEA diharapkan akan menjadi kekuatan ekonomi baru di dunia yang dapat menghubungkan antara negara-negara yang ekonominya belum berkembang (Kamboja, Myanmar, Laos, Vietnam), dengan negaranegara yang ekonominya sudah maju (Brunei, Singapura, Malaysia, Thailand, Filipina, Indonesia), dan dapat membawa perkembangan ekonomi yang merata di kawasan ini. Dengan menjadi basis produksi dan pasar tunggal Asean, MEA akan meningkatkan daya saing dan konektivitas antar wilayah di Asean.

3. Indonesia memiliki daya saing terbaik di Asean untuk ukuran besarnya pasar (market size) yang ada. Dengan jumlah penduduk terbesar di Asean maka ukuran pasar potensial di Indonesia sangat besar, dan ini menjadi daya tarik bagi negara-negara di dunia dan Asean untuk menjual produknya di Indonesia.

4. Dilain pihak, daya saing efisiensi pasar tenaga kerja (labormarketefficiency) Indonesia sangat rendah. Hal ini bisa disebabkan oleh pendidikan dan keahlian tenaga kerja kita yang rendah dan seringnya terjadi tuntutan/demonstrasi tenaga kerja di Indonesia yang menuntut kenaikan upah dan fasilitas lainnya. Oleh karena itu, efisiensi pasar tenaga kerja perlu diperbaiki dengan meningkatkan ketrampilan dan keahlian tenaga kerja kita dan memperbaiki kebijakan terkait ketenaga kerjaan (peraturanperaturan).

5. Indeks daya saing Indonesia berada di posisi 5 besar teratas di Asean, lebih baik daripada negara-negara Vietnam, Laos, Kamboja, dan Myanmar. Meskipun demikian, kelembagaan, infrastruktur, makro ekonomi, kesehatan, pendidikan, pasar uang, teknologi dan inovasi masih perlu ditingkatkan agar negara kita meningkat daya saingnya dan menjadi pemenang dalam persaingan di pasar tunggal MEA.

\section{DAFTAR PUSTAKA}

Basri, Faisal. 2002, Perekonomian Indonesia: Tantangan dan Harapan bagi kebangkitan

Indonesia.jakarta:Erlangga.

Hutapea, Rita Uli. 2016.AS dan Filipina gelar patroli gabungan di Laut China
Selatan, detikNews, www.detik.com, 14/4/2016.

Low, Patrick. 2016.Asean Economic Community faces numerous challenges, http://asiaglobalinstitute.hku. hk, 6 Januari 2016.

Schwab, Klaus. 2014.The Global competitiveness report 20I4-20I5, World Economic Forum, Genewa-Swiss, 2014.

Sellier, Elodie. 2016. , The ASEAN Economic Community: The Force Awakens?, The Diplomat.com, 12 Januari 2016.

Tambunan, Tulus 2012, Perekonomian Indonesia: Kajian Teoritis dan Analisis Empiris,Jakarta: Ghalia Indonesia, 